\title{
Coumarins and Xanthones from the Seeds of Mammea siamensis
}

\author{
Surat Laphookhieo, ${ }^{* a}$ Phunrawie Promnart, ${ }^{a}$ John Keith Syers, ${ }^{a}$ Akkharawit Kanjana-Opas, ${ }^{b}$ \\ Chanita Ponglimanont ${ }^{c}$ and Chatchanok Karalai ${ }^{c}$ \\ ${ }^{a}$ School of Science, Mae Fah Luang University, Tasud, Muang, Chiang Rai 57100, Thailand \\ ${ }^{b}$ Department of Industrial Biotechnology, Faculty of Agro-Industry, Prince of Songkla University, \\ Hat-Yai, Songkhla 90112, Thailand \\ ${ }^{c}$ Department of Chemistry, Faculty of Science, Prince of Songkla University, Hat-Yai, \\ Songkhla 90112, Thailand
}

\begin{abstract}
Uma cumarina inédita, mammea E/BB ciclo D (1), juntamente com cinco compostos conhecidos, mammea E/BA ciclo D (2), suragina C (3), terapina B (4), 1,7-dihidroxixantona (5) e 1-hidróxi-5-metoxyxantona (6), foram isolados de sementes de Mammea siamensis. Suas estruturas foram caracterizadas usando dados de RMN 1D e 2D. Suragina C e terapina B mostraram atividade citotóxica contra adenocarcinoma de mama (MCF-7), câncer cervical humano (HeLa), câncer de colon (HT-29) e câncer oral humano (KB).
\end{abstract}

A new coumarin, mammea E/BB cyclo D (1), together with five known compounds, mammea E/BA cyclo D (2), suragin C (3), therapin B (4), 1,7-dihydroxyxanthone (5) and 1-hydroxy-5methoxyxanthone (6), were isolated from the seeds of Mammea siamensis. Their structures were characterized using 1D and 2D NMR spectral data. Suragin C and therapin B showed cytotoxic activity against breast adenocarcinoma (MCF-7), human cervical cancer (HeLa), colon cancer (HT-29) and human oral cancer (KB).

Keywords: mammea E/BB cyclo D, cytotoxic activity, Mammea siamensis, guttiferrae

\section{Introduction}

Mammea siamensis (Miq) T. Anders. (Guttiferae), known in Thai as "Sarapi", is a small evergreen tree distributed in Thailand, Laos, Cambodia, Vietnam and Myanmar. The flowers of this plant have been used in traditional Thai medicine as a heart tonic. Investigations of different parts of the plant have revealed the presence of several coumarins and xanthones. ${ }^{1-4}$ We have previously reported the isolation and structure determination of phenolic compounds from the seeds of this species. ${ }^{5}$ In a continuation of our study on this plant, we now report herein the isolation and structure elucidation of a novel compound, mammea $\mathrm{E} / \mathrm{BB}$ cyclo $\mathrm{D}$ (1), together with three known coumarins, mammea E/BC cyclo D (2), ${ }^{3}$ suragin C (3), ${ }^{6}$ therapin B $(\mathbf{4})^{7}$ and two known xanthones, 1,7-dihydroxyxanthone $(\mathbf{5})^{8}$ and 1-hydroxy-5methoxyxanthone $(6)^{9}$ from the $\mathrm{CH}_{2} \mathrm{Cl}_{2}$ extract (Figure 1). The cytotoxic activity of all isolates is also reported.

*e-mail: surat@mfu.ac.th; laphookhieo@yahoo.com

\section{Experimental}

\section{General procedures}

Melting points were determined using a Fisher-John melting point apparatus. The optical rotation $[\alpha]_{D}$ values were determined with a JASCO P-1020 polarimeter. UV spectra were measured with a UV-160A spectrophotometer (Shimadzu). The IR spectra were measured with a PerkinElmer FTS FT-IR spectrophotometer. The ${ }^{1} \mathrm{H}$ and ${ }^{13} \mathrm{C}$ NMR spectra were recorded using $500 \mathrm{MHz}$ Varian UNITY INOVA and $300 \mathrm{MHz}$ Bruker FTNMR Ultra Shield ${ }^{\mathrm{TM}}$ spectrometers. Chemical shifts were recorded in parts per million $(\delta)$ in $\mathrm{CDCl}_{3}$ with tetramethylsilane (TMS) as an internal reference. The EIMS was obtained from a MAT 95 XL mass spectrometer. Quick column chromatography (QCC) and column chromatography (CC) were carried out on silica gel $60 \mathrm{~F}_{254}$ (Merck, 230-400 Mesh ASTM) and silica gel 100 (Merck, 70-230 Mesh ASTM), respectively. Precoated plates of silica gel $60 \mathrm{~F}_{254}$ and reversed-phase $\left(\mathrm{RP}-18 \mathrm{~F}_{254 \mathrm{~S}}\right.$ ) were used for analytical purposes. 


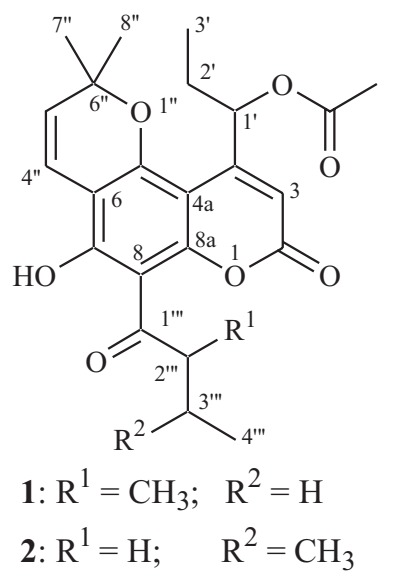

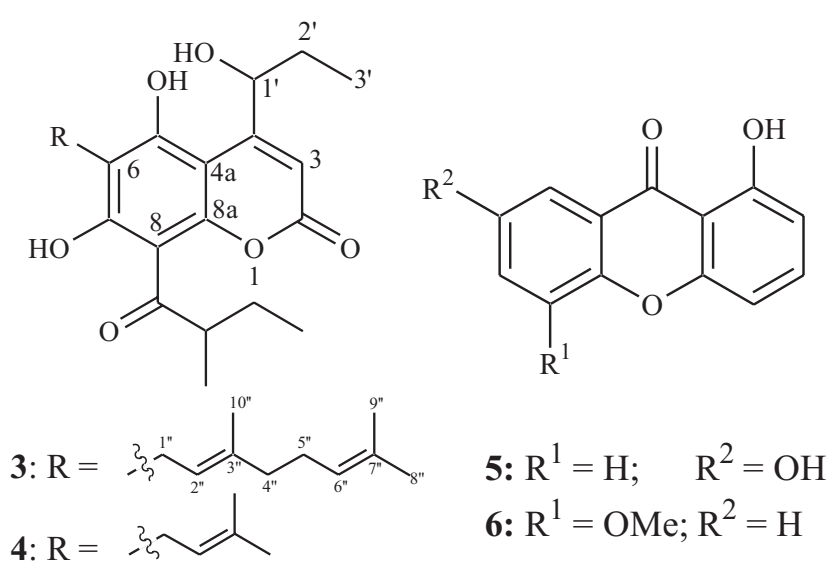

Figure 1. Structures of compounds 1-6.

\section{Plant material}

The seeds of M. siamensis were collected from Mae Fah Luang University, Tasud, Muang, Chiang Rai Province, northern Thailand in August 2005. The identification was made by Professor Puangpen Sirirugsa, Department of Biology, Faculty of Science, Prince of Songkla University and a voucher specimen (No. SC09) was deposited at Prince of Songkla University Herbarium.

\section{Extraction and Isolation}

The seeds (224.5 g) of M. siamensis were extracted successively with $\mathrm{CH}_{2} \mathrm{Cl}_{2}(500 \mathrm{~mL})$ at room temperature for 5 days. The filtered samples were combined and the solvents were evaporated under reduced pressure to provide the $\mathrm{CH}_{2} \mathrm{Cl}_{2}$ extracts $(44.4 \mathrm{~g})$.

The $\mathrm{CH}_{2} \mathrm{Cl}_{2}$ extract (44.4 g) was chromatographed by QCC and eluted with hexane-EtOAc mixtures to give seven fractions (F1-F7). Fraction F2 (1.92 g) was purified by RP$18 \mathrm{CC}$ with acetone: $\mathrm{H}_{2} \mathrm{O}$ (3:1) and followed by RP-18 preparative TLC with acetone: $\mathrm{H}_{2} \mathrm{O}$ (3:1) to yield $\mathbf{1}$ (3.1 $\mathrm{mg}$ ) and 2 (4.3 $\mathrm{mg})$. Fraction F4 (3.35 g) was separated by CC with EtOAc: hexane (3:17) and followed by RP-18 preparative TLC with $\mathrm{MeOH}: \mathrm{H}_{2} \mathrm{O}$ (4:1) to provide five subfractions (F4a-F4e). Subfraction F4b (12.8 mg) was purified by preparative TLC with EtOAc: hexane (1:3, v/ v) to give $5(2.1 \mathrm{mg})$. Subfraction F4d $(1.02 \mathrm{~g})$ was purified by RP-18 CC with $\mathrm{MeOH}: \mathrm{H}_{2} \mathrm{O}$ (4:1) and followed by CC with EtOAc: hexane (1:3) to afford $\mathbf{4}(16.8 \mathrm{mg})$ and $\mathbf{3}$ (32.6 $\mathrm{mg})$. Fraction F6 (167.0 mg) was separated by CC with EtOAc: hexane $(2: 3, \mathrm{v} / \mathrm{v})$ to give $6(6.3 \mathrm{mg})$.

Mammea E/BB cyclo D (1)

Yellowish viscous oil; ${ }^{1} \mathrm{H}$ NMR $\left(\delta, \mathrm{CDCl}_{3}, 300 \mathrm{MHz}\right)$ :
$14.44(7-\mathrm{OH}), 6.74\left(1 \mathrm{H}, \mathrm{d}, J 10.0 \mathrm{~Hz}, \mathrm{H}-4^{\prime \prime}\right), 6.60(1 \mathrm{H}$, dd, $\left.J 6.8,2.8 \mathrm{~Hz}, \mathrm{H}-1^{\prime}\right), 6.30(1 \mathrm{H}, \mathrm{s}, \mathrm{H}-3), 5.60(1 \mathrm{H}, \mathrm{d}, J$ $\left.10.0 \mathrm{~Hz}, \mathrm{H}-5^{\prime \prime}\right), 4.02$ (1H, sextet, J $\left.6.3 \mathrm{~Hz}, \mathrm{H}-2^{\prime \prime \prime}\right), 2.17$ $\left(3 \mathrm{H}, \mathrm{s}, \mathrm{H}-1^{\prime}-\mathrm{COCH}_{3}\right), 1.97$ (1H, m, H-2'a), $1.80(1 \mathrm{H}, \mathrm{m}$, H-3"'a), 1.78 (1H, m, H-2'b), 1.58 (3H, s, H-7"), 1.56 $\left(3 \mathrm{H}, \mathrm{s}, \mathrm{H}-8^{\prime}\right), 1.45$ (1H, $\left.m, \mathrm{H}-3^{\prime \prime \prime} \mathrm{b}\right), 1.26(3 \mathrm{H}, \mathrm{d}, J 6.3 \mathrm{~Hz}$, H-5'"), 1.07 (3H, t, J 7.2 Hz, H-3') and 1.06 (3H, t, J 7.2 $\left.\mathrm{Hz}, \mathrm{H}-4^{\prime \prime \prime}\right) ;{ }^{13} \mathrm{C}$ NMR data $\left(\mathrm{CDCl}_{3}, 75 \mathrm{MHz}\right): 210.8$ (C$\left.1^{\prime \prime \prime}\right), 170.3\left(\mathrm{CH}_{3} \mathrm{CO}\right), 163.5(\mathrm{C}-7), 159.3(\mathrm{C}-2), 157.5(\mathrm{C}-$ 4), 156.7 (C-8a), 155.7 (C-5), 126.8 (C-5"), 115.8 (C4"), 106.5 (C-6), 106.4 (C-3), 103.7 (C-8), 100.9 (C-4a), 80.2 (C-6"), $73.0\left(\mathrm{C}-1^{\prime}\right), 46.9$ (C-2'"'), 29.6 (C-3"') $), 28.6$ (C-2'), 28.4 (C-7"), 27.8 (C-8"), $21.0\left(\mathrm{CH}_{3} \mathrm{CO}\right), 16.9$ (C$\left.5^{\prime \prime \prime}\right), 10.6$ (C-4'"'), 10.0 (C-3'); EIMS m/z (rel. int.): 428 $[\mathrm{M}]^{+}$(39), 413 (100), 371 (45), 353 (13), 311 (29), 283 (5); HREIMS $\mathrm{m} / \mathrm{z}[\mathrm{M}]^{+} 428.1813$ (calc. for $\mathrm{C}_{24} \mathrm{H}_{28} \mathrm{O}_{7}$, 428.1835); UV(MeOH) $\lambda_{\text {max }}$ /nm: 225, 280, 285, 300, 373; $\mathrm{IR}\left(\mathrm{CHCl}_{3}\right) \nu_{\max } / \mathrm{cm}^{-1}: 3454,1738,1655,1605 ;[\alpha]_{\mathrm{D}}^{27}-15.0^{\circ}$ (c $0.10, \mathrm{MeOH})$.

\section{Cytotoxicity assay}

The procedure for cytotoxic assay was performed by sulphorhodamine B (SRB) assay as described by Skehan et al. ${ }^{10}$ In this study, four cancer cell lines, MCF-7 (breast adenocarcinoma), HeLa (human cervical cancer), HT-29 (colon cancer) and KB (human oral cancer) were used. Camptothecin, the reference substance, exhibited activity toward MCF-7, HeLa, HT-29 and KB cell lines, with $\mathrm{IC}_{50}$ range of 0.2-2.0 $\mu \mathrm{g} \mathrm{mL}^{-1}$ (Table 1).

\section{Results and Discussion}

Mammea E/BB cyclo D (1) was isolated as a yellowish viscous oil, with a molecular formula $\mathrm{C}_{24} \mathrm{H}_{28} \mathrm{O}_{7}$, established 
Table 1. Cytotoxic activity of compounds 1-6

\begin{tabular}{lcccc}
\hline \multirow{2}{*}{ Compound } & \multicolumn{4}{c}{$\mathrm{IC}_{50} /\left(\mu \mathrm{g} \mathrm{mL} \mathrm{mL}^{-1}\right)$} \\
\cline { 2 - 5 } & MCF-7 $^{\mathrm{a}}$ & $\mathrm{Hela}^{\mathrm{b}}$ & $\mathrm{HT}^{2} \mathrm{c}^{\mathrm{c}}$ & $\mathrm{KB}^{\mathrm{d}}$ \\
\hline $\mathbf{1}$ & Inactive & Inactive & Inactive & Inactive \\
$\mathbf{2}$ & Inactive & Inactive & Inactive & Inactive \\
$\mathbf{3}$ & 1.33 & 2.56 & 0.78 & 1.33 \\
$\mathbf{4}$ & 4.64 & 3.52 & 4.06 & 4.06 \\
$\mathbf{5}$ & Inactive & Inactive & Inactive & Inactive \\
$\mathbf{6}$ & Inactive & Inactive & Inactive & Inactive \\
Camptothecin & $0.2-2.0$ & $0.2-2.0$ & $0.2-2.0$ & $0.2-2.0$ \\
\hline
\end{tabular}

aCF-7 (breast adenocarcinoma), ${ }^{\mathrm{b}} \mathrm{HeLa}$ (human cervical cancer), ${ }^{\mathrm{c}} \mathrm{HT}$ 29 (colon cancer) and ${ }^{\mathrm{d}} \mathrm{KB}$ (human oral cancer).

by HREIMS analysis of its molecular ion [M] ${ }^{+}$at $\mathrm{m} / \mathrm{z}$ 428.1813 (Calc. for $\mathrm{C}_{24} \mathrm{H}_{28} \mathrm{O}_{7} \mathrm{~m} / z$ 428.1835). The UV spectrum of 1 showed absorption bands at 225, 280, 285, 300 and $373 \mathrm{~nm}$ suggesting the presence of conjugation in the molecule. The IR spectrum exhibited the characteristic of carbonyl (1738 and $1655 \mathrm{~cm}^{-1}$ ) and hydroxyl $\left(3454 \mathrm{~cm}^{-1}\right)$ functionalities. The ${ }^{13} \mathrm{C}$ NMR and DEPT spectra revealed 24 carbons, including six methyls ( $\delta$ 10.0, 10.6, 16.9, 21.1, 27.8 and 28.4), two methylenes ( $\delta 28.6$ and 29.6), five methines $(\delta 46.9,73.0,106.4,115.8$ and 126.8) and eleven non-hydrogenated carbons $(\delta 80.2$, 100.9, 103.7, 106.5, 155.7, 156.7, 157.5, 159.3, 163.5, 170.3 and 210.8). The ${ }^{1} \mathrm{H}$ NMR spectral data showed a chelated hydroxyl proton at $\delta 14.44$ assignable to 7-OH on the basis of HMBC correlations (Figure 2). The ${ }^{1} \mathrm{H}$ NMR spectrum also displayed a singlet signal at $\delta 6.30$, which is a typical chemical shift for $\mathrm{H}-3$ of 4alkylcoumarin skeleton. ${ }^{3,11}$ In addition, the ${ }^{1} \mathrm{H}$ NMR spectrum also showed the signals of chromene ring, 2methyl-1-oxobutyl and 1-acetoxypropyl moieties. The ${ }^{1} \mathrm{H}$ NMR signals of chromene ring were appeared at $\delta 6.74$ $\left(1 \mathrm{H}, \mathrm{d}, J 10.0 \mathrm{~Hz}, \mathrm{H}-4^{\prime \prime}\right), 5.60$ (1H, d, $\left.J 10.0 \mathrm{~Hz}, \mathrm{H}-5^{\prime \prime}\right)$, $1.58\left(3 \mathrm{H}, \mathrm{s}, \mathrm{H}-7^{\prime \prime}\right)$ and $1.56\left(3 \mathrm{H}, \mathrm{s}, \mathrm{H}-8^{\prime \prime}\right)$, while the 2methyl-1-oxobutyl group showed signals at $\delta 4.02(1 \mathrm{H}$,

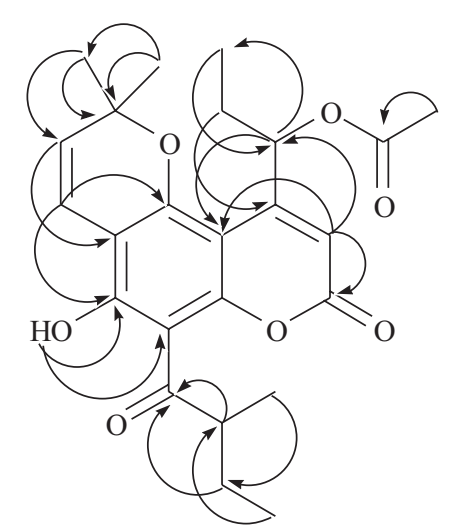

Figure 2. Selective HMBC correlations of compound $\mathbf{1 .}$ sextet, $\left.J 6.3 \mathrm{~Hz}, \mathrm{H}-2^{\prime \prime \prime}\right), 1.80$ (1H, m, H-3"'a), 1.45 (1H, m, H-3"b), 1.26 (3H, d, J $\left.6.3 \mathrm{~Hz}, \mathrm{H}-5^{\prime \prime \prime}\right)$ and 1.06 (3H, t, $\left.J 7.2 \mathrm{~Hz}, \mathrm{H}-4^{\prime \prime \prime}\right)$. Finally, the 1-acetonylpropyl moiety showed the ${ }^{1} \mathrm{H}$ NMR signals at $\delta 6.60(1 \mathrm{H}, \mathrm{dd}, J 6.8,2.8$ $\left.\mathrm{Hz}, \mathrm{H}-1^{\prime}\right), 2.17\left(3 \mathrm{H}, \mathrm{s}, \mathrm{H}-1^{\prime}-\mathrm{COCH}_{3}\right), 1.97(1 \mathrm{H}, \mathrm{m}, \mathrm{H}-$ 2'a), $1.78\left(1 \mathrm{H}, \mathrm{m}, \mathrm{H}-2^{\prime} \mathrm{b}\right)$, and $1.07\left(3 \mathrm{H}, \mathrm{t}, J 7.2 \mathrm{~Hz}, \mathrm{H}-3^{\prime}\right)$. The locations of the three moieties were established based on the observed key HMBC correlations (Figure 2). The 1 -acetoxypropyl unit was placed at C-4 due to the oxymethine proton $\mathrm{H}^{-} 1^{\prime}\left(\delta\right.$ 6.60) showed ${ }^{2} J$ and ${ }^{3} J$ correlation with C-4a $(\delta 100.9), \mathrm{C}-4(\delta 157.5)$ and C-3 $(\delta$ $106.4)$ in the HMBC spectrum. In addition, the olefinic proton H-3 $(\delta 6.30)$ also showed ${ }^{2} J$ and ${ }^{3} J$ correlations with $\mathrm{C}-1^{\prime}(\delta 73.0), \mathrm{C}-2(\delta$ 159.3) and C-4a $(\delta 100.9)$. The chromene ring was located at $\mathrm{C}-5 / \mathrm{C}-6$ because the olefinic proton $\mathrm{H}-4$ " $(\delta$ 6.74) displayed HMBC correlations to C$5(\delta$ 155.7), C-6 $(\delta 106.5)$ and C-7 $(\delta 163.5)$. Finally, the hydroxyl group was located at $\mathrm{C}-4$ because the chelated hydroxyl proton showed HMBC correlations to C-6 $(\delta$ $106.5), \mathrm{C}-7(\delta 163.5)$ and C-8 $(\delta 103.7)$ and the 2-methyl1-oxobutyl moiety had to be placed at C- 8 by process of elimination. Therefore, the structure of mammea $\mathrm{E} / \mathrm{BB}$ cyclo D was characterized as $\mathbf{1}$.

The reported compounds were tested for their cytotoxicity against MCF-7 (breast adenocarcinoma), HeLa (human cervical cancer), HT-29 (colon cancer) and KB human oral cancer) cell lines. The results are summarized in Table 1. Only two coumarins, $\mathbf{3}$ and $\mathbf{4}$, were found to be active in this study. Suragin C (3) showed cytotoxic activities against all four cancer cell lines better than therapin B (4) (Table 1). It should be noted that the structural difference between suragin $\mathrm{C}(\mathbf{3})$ and therapin B (4) is only at C-6 (3 possesses a geranyl group while 4 contains a prenyl group). The presence of a geranyl moiety seems to be important for enhancing the cytotoxic activity. The anticancer drug used as a standard in our cytotoxic assay is camptothecin, which has an $\mathrm{IC}_{50}$ in the range of $0.2-2.0 \mu \mathrm{g} \mathrm{mL} \mathrm{m}^{-1}$.

It is worth noting that the genus Mammea of the family Guttiferae has been known to be rich in coumarins and xanthones, ${ }^{1-5,9,12-17}$ with more than 30 compounds having been isolated from this genus. In this study, we have observed an additional new coumarin from the seeds of M. siamensis.

\section{Acknowledgments}

We are grateful to Mae Fah Luang University for financial support (Grant No. 49101020005). We also thank Professor Puangpen Sirirugsa, Department of Biology, Faculty of Science, Prince of Songkla University for plant identification. 


\section{References}

1. Thebtaranonth, C.; Imraporn, S.; Padungkul, N.; Phytochemistry 1981, 20, 2305.

2. Poobrasert, O.; Constant, H. L.; Beecher, C. W. W.; Farnsworth, N. R.; Kinghorn, A. D.; Pezzuto, J. M.; Cordell, G. A; Santisuk, T.; Reutrakul, V.; Phytochemistry 1998, 47, 1661.

3. Mahidol, C.; Kaweetripob, W.; Prawat, H.; Ruchirawat, S.; J. Nat. Prod. 2002, 65, 757.

4. Prachyawarakorn, V.; Mahidol, C.; Ruchirawat, S.; Phytochemistry 2006, 67, 924.

5. Laphookhieo, S.; Maneerat, W.; Kiattansakul, R.; Can. J. Chem. 2006, $84,1546$.

6. Mahandru, M. M.; Ravindran, V. K.; Phytochemistry 1986, 25, 555.

7. Lee, K. H.; Chai, H. B.; Tamez, P. A.; Pezzuto, J. M.; Cordell, G. A.; Win, K. K.; Tin-Wa, M.; Phytochemistry 2003, 64, 535.

8. Nagam T. J.; de Oliveira, F. F.; J. Braz. Chem. Soc. 1997, 8, 505.

9. Gunasekera, S. P.; Ramachandran, S.; Selliah, S.; Sultanbawa, M. U. S.; J. Chem. Soc., Perkin Trans. 1 1975, 2447.
10. Skehan, P.; Storeng, R.; Scudiero, D.; Monks, A.; Mcmahon, J.; Vistica, D.; Warren, J. T.; Bokesch, H.; Kenney, S.; Boyd, M. R.; J. Natl. Cancer Inst. 1990, 82, 1107.

11. Cruz, F. G.; da Silva-Neto, J. T.; Guedes, M. L. S.; J. Braz. Chem. Soc. 2001, 12, 117.

12. Reutrakul, V.; Leewanich, P.; Tuchinda, P.; Pohmakotr, M.; Jaipetch, T.; Sophasan, S.; Santisuk, T.; Planta Med. 2003, 69, 1048.

13. Kaweetripob, W.; Mahidol, C.; Prawat, H.; Ruchirawat, S.; Pharm. Biol. 2000, 38, 55.

14. Prachyawarakorn, V.; Mahidol, C.; Ruchirawat, S.; Pharm. Biol. 2000, 38, 58.

15. Combie, L.; Jones, R. C. F.; Palmer, C. J.; J. Chem. Soc. Perkin Trans. 1, 1987, 345.

16. Tosa, H.; Inuma, M.; Murakami, K-I.; Ito, T.; Tanaka, T.; Chelladurai, V.; Riswan, S.; Phytochemistry 1997, 45, 133.

17. Iinuma, M.; Tosa, H.; Tanaka, T.; Riswan, S.; Phytochemistry 1996, 42, 245.

Received: January 9, 2007

Web Release Date: August 6, 2007 